\title{
Testing Rhizobia for Natural and Anthropogenic Saline Soils and Subsoils
}

\author{
Leonid Skipin' ${ }^{1}$ Elena Gaevaya', Svetlana Tarasova ${ }^{1 *}$ \\ 1 Industrial University of Tyumen, Volodarskogo 38, 652000 Tyumen, Russia \\ *Corresponding author's e-mail: tarasovass@tyuiu.ru
}

\begin{abstract}
The area of naturally saline lands in Russia is approximately 30 million hectares. Currently, the growth of anthropogenic saline areas is associated with the extraction of minerals (agricultural ore) and the formation of drilling pits when drilling wells for the exploration and extraction of hydrocarbons. The number of drilling pits with high salt content in the Khanty-Mansi Autonomous Okrug is about 3 thousand. About the same number of them is found in the Yamalo-Nenets Autonomous Okrug. In the south of the Tyumen region, their number is increasing in the Uvat district. Reclamation of these areas includes the technical and biological phases of reclamation. The biological stage involves the use of phytomeliorant crops. Inclusion of the legume component in phytomeliorants implies its joint use with a preparation of active strain of nodule bacteria. The aim of the research was to identify the most salt-tolerant strain of lupine nodule bacteria under different chemistry and degree of salinity of the environment. In order to test lupine rhizobia for salt tolerance and salinity chemistry, laboratory experiments were set up in petri dishes. Lupine rhizobia strains 363a, 367a, and 375a were taken directly from the rhizotorphin preparations, and the degree of dilution was brought to a certain titer corresponding to about 80 colonies per Petri dish. The presented results of the experiments showed that the colonies of lupine rhizobia react extremely negatively to the concentration of salts in the nutrient medium of $0.3 \%$ or higher. This is true for both neutral and sodium salinity. Out of the three strains of rhizobia studied, sample 367a was the most salt tolerant. Strains $363 \mathrm{a}$ and $375 \mathrm{a}$ were less resistant to salinization. For the first time, strains of lupine rhizobia were tested for salt tolerance in relation to different chemistry and degree of salinity identical to anthropogenic soils and saline soils.
\end{abstract}

Keywords: Rhizobia (nodule bacteria), colonies, chemistry and degree of salinity, osmotic pressure, strains, $\mathrm{pH}$ of the medium.

\section{INTRODUCTION}

The reclamation of natural and anthropogenic saline areas at the biological stage can be achieved through the proper introduction of phytomeliorant crops. For alkaline soils, among the legume components, melilotus and medicago are of the greatest interest in this regard. Under the conditions of the taiga-forest zone, the legume component represented by lupine is of particular interest for the drilling pit sites. Reclamation of such limitedly disturbed areas is constrained by nitrogen deficiency; its production and delivery to the northern parts of the Tyumen region involve large financial and material costs [Petukhova V.S. et al. 2017].
The use of biological nitrogen in the remediation of soils and technogenic saline soils contributes to reducing the energy costs, saving material resources, reducing environmental pollution even at the stage of nitrogen fertilizer production [Laktionov et al. 2019].

For the conditions of Western Siberia, the use of the legume component during reclamation works is relevant and timely, since of all nutrition elements for plants, nitrogen is in the first minimum. With saline soils and subsoils, it is even stronger [Saksaganskaya et al. 2016, Saksaganskaya et al. 2017].

To date, the activity of rhizobia in drill cuttings remains very poorly studied. At the same 
time, the increase in the number of drilling pits requires the need for their timely reclamation with maximum use of the legume component [Skipin et al. 2014]. In this regard, the study of the factors determining the activity of rhizobia under saline conditions deserves great attention. It was found that under favorable factors of symbiosis, legumes can accumulate up to $200 \mathrm{~kg} / \mathrm{ha}$ of nitrogen during the summer season [Posypanov, 1991.].

One of the most important conditions for symbiosis productivity is the selection of the most active strains of rhizobia for preparations. The strains must have the ability to occupy a dominant position in the rhizosphere of legumes. It is important that they are resistant to adverse environmental factors: increased acidity or salinity, drastic temperature fluctuations, etc. [Patent for invention RU 2593714 C1. 2015, Laktionov et al. 2018].

The purpose and objectives of the research were to identify the most salt-tolerant strain of lupine rhizobia under different chemistries and degrees of salinity.

\section{MATERIAL AND METHODS}

In order to test lupine rhizobia for salt tolerance and salinity chemistry, laboratory experiments were set up in Petri dishes. Lupine rhizobia strains 363a, 367a, and 375a were taken directly from the rhizotorphin preparations, and the degree of dilution was brought to a certain titer corresponding to about 80 colonies per a Petri dish. The bean agar was made of 50 grams of peas, one liter of tap water, 10 grams of sucrose, 0.5 grams of $\mathrm{K}_{2} \mathrm{PO}_{4}, 20$ grams of agar and the amount of salt corresponding to the studied variant. Salts are presented as follows: $\mathrm{MgSO}_{4}, \mathrm{Na}_{2} \mathrm{SO}_{4}, \mathrm{NaCl}$, $\mathrm{NaHCO}_{3}, \mathrm{Na}_{2} \mathrm{CO}_{3}$, and sulfate-chloride salination. The experiments were performed in 3-fold repetition; when colonies appeared after sowing, they were counted and cultural features were described. The methodology of laboratory experiments was described by G.I. Yezhov [Yezhov 1981.].

\section{RESULTS}

Water-soluble salts largely determine the activity of nitrogen fixation on saline media. Salts can have a direct effect on rhizobia by increasing the osmosis of the solution, the $\mathrm{pH}$ of the medium and the toxicity of a number of ions; under soil conditions, this is further enhanced by the deterioration of water-physical properties. According to scientists, the salt concentration over $1 \%$ significantly inhibits, and over $4 \%$ - hinders the development of microorganisms. Some of them also function steadily at higher salt concentrations. At the same time, the nature of salinity is not indicated and the group of bacteria is not specified [Yakobi et al. 2019, Yakobi et al. 2018].

The set-up in laboratory experiments was aimed at studying the direct effect of the degree and type of salinity, and as a consequence, the value of osmosis and $\mathrm{pH}$ of the medium, on the number of colonies of different lupine strains. In order to set up laboratory experiments, lupin nodule bacteria represented by strains $363 \mathrm{a}, 367 \mathrm{a}$, and $375 \mathrm{a}$ were taken from rhizotorphin. In the experiments carried out, easily soluble salts with a given concentration of $\mathrm{MgSO}_{4}, \mathrm{Na}_{2} \mathrm{SO}_{4}, \mathrm{NaCl}$ have $\mathrm{pH}$ of 6.3-6.8, and osmotic pressure of 3.0 to $14.0 \mathrm{~atm} ; \mathrm{NaHCO}_{3}, \mathrm{Na}_{2} \mathrm{CO}_{3}$ have $\mathrm{pH}$ of 9.0 to 10.6 , and osmotic pressure of 3.0 to $7.1 \mathrm{~atm}$; sulfate-chloride salination has $\mathrm{pH}$ of 6.6-9.0, and osmotic pressure of 1.3 to $9.4 \mathrm{~atm}$ [Rumyantseva et al. 2019, Rumyantseva et al. 2018].

Studies have shown that the degree of salinity of the nutrient mixture with highly soluble salts largely determines the activity of lupine rhizobia. Bringing the concentration of bean agar to $0.3 \%$ neutral salinity already reduced the number of rhizobia colonies from 80 in the control to 3-47 (Fig. 1-4).

This was manifested at a neutral medium reaction $(\mathrm{pH}=6.7)$ and an osmotic pressure of 3.14-4.10 atm. This phenomenon indicates that the death of lupine rhizobia colonies in neutral salinity is largely determined by the osmotic pressure and ion toxicity. Subsequent increase in the concentrations of neutral salts is associated with a suppression of colony activity relative to the control variant. It is important to note that the negative effect of $\mathrm{MgSO}_{4}$ was somewhat less pronounced on colony germination than that of the neutral sodium salts $\left(\mathrm{Na}_{2} \mathrm{SO}_{4}, \mathrm{NaCl}\right)$. Out of all the presented strains of nodule bacteria under neutral chemistry, strain 367a had the highest salt tolerance; strains $375 \mathrm{a}$ and 363a were less resistant to saline medium. This appeared in respect to each gradation of the salinity level.

For sodium salinity $\left(\mathrm{NaHCO}_{3}\right.$ and $\left.\mathrm{Na}_{2} \mathrm{CO}_{3}\right)$, a salinity degree of $0.3 \%$ caused an aqueous 


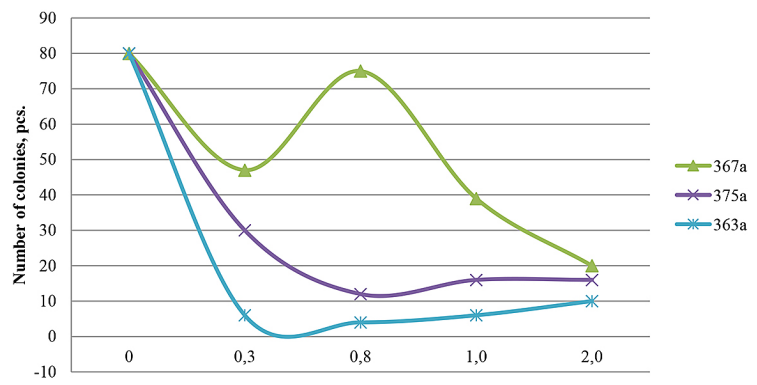

Fig. 1. Assessment of resistance of lupine rhizobia strains to $\mathrm{MgSO}_{4}$ salination, \%

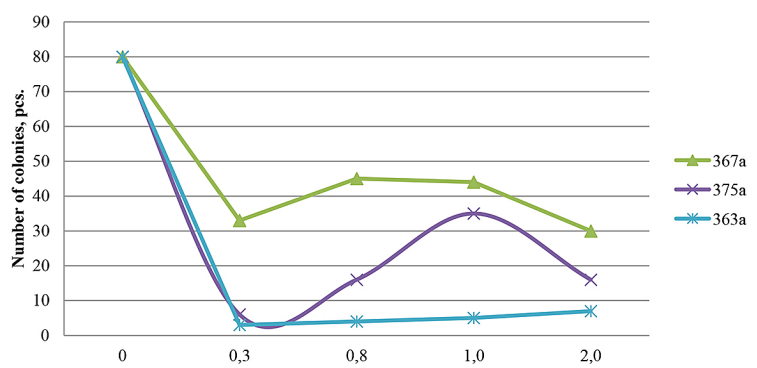

Fig. 3. Assessment of resistance of lupine rhizobia strains to $\mathrm{NaCl}$ salination, \%

medium reaction of 9.2-9.8 at an osmotic pressure of 3.90-4.32 atm. The number of lupine rhizobia colonies in Petri dishes decreased from 80 to $4-45$ pcs. (Fig. 5, 6). Maximum colony death was observed with regular washing soda $\left(\mathrm{Na}_{2} \mathrm{CO}_{3}\right)$ salinity. The strain $367 \mathrm{a}$ was also the most resistant to sodium salinity, especially when sodium bicarbonate was added to the nutrient substrate. The death of the rhizobia colonies in sodium salinization was caused by an increased alkaline $\mathrm{pH}$ of the medium.

The sulfate-chloride salinity did not weaken the negative effect on the activity of lupine rhizobia colonies in comparison with $\mathrm{Na}_{2} \mathrm{SO}_{4}$ and $\mathrm{NaCl}$ saline media separately. At this chemistry, the advantage in the number of the rhizobia bacteria

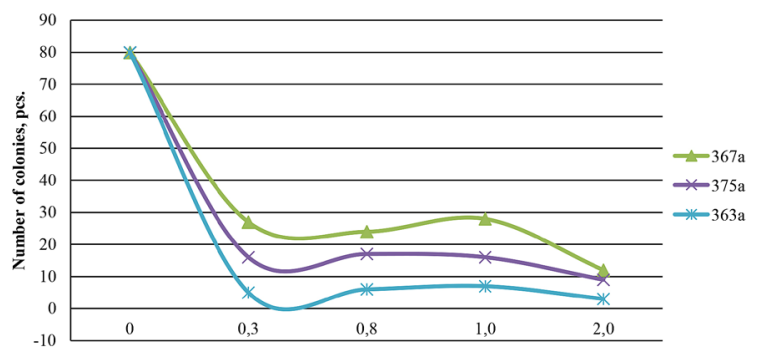

Fig. 5. Assessment of resistance of lupine rhizobia strains to $\mathrm{Na}_{2} \mathrm{CO}_{3}$ salination, \%

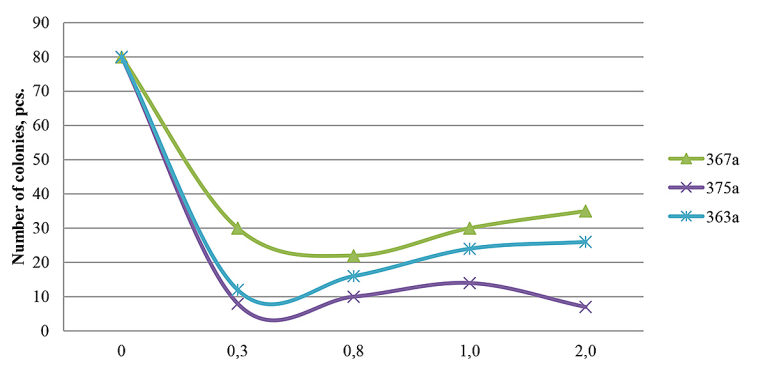

Fig. 2. Assessment of resistance of lupine rhizobia strains to $\mathrm{Na}_{2} \mathrm{SO}_{4}$ salination, $\%$

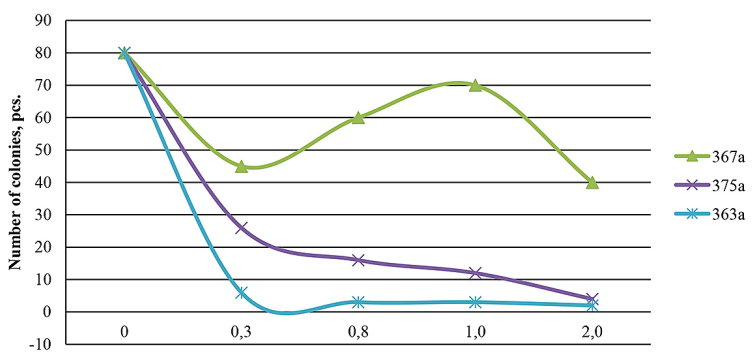

Fig. 4. Assessment of resistance of lupine rhizobia strains to $\mathrm{NaHCO}_{3}$ salination, \%

colonies at all concentrations studied was still retained by strain $367 \mathrm{a}$.

It is important to note that in the previous studies conducted on nodule bacteria of Melilotus and Medicago, the optimal degree of salinity for them at neutral salinity ranged from 0.3 to $0.8 \%$ [Skipin 2000]. A similar degree of salinity for lupine rhizobia suppresses their activity relative to the control.

\section{CONCLUSIONS}

Thus, the presented results of the experiments showed that the colonies of lupine nodule bacteria react extremely negatively to the concentration of salts in the nutrient medium of $0.3 \%$ or higher.

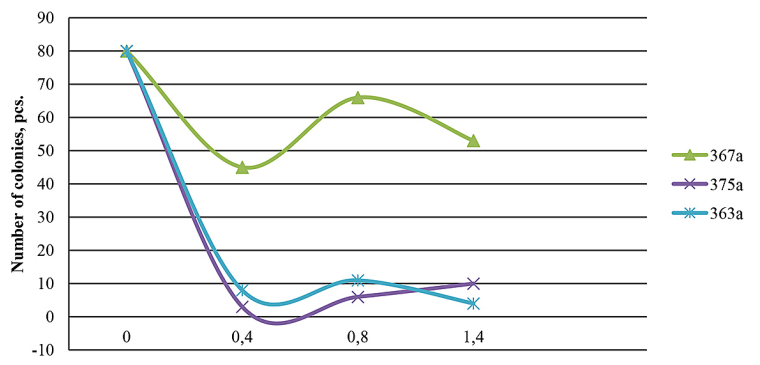

Fig. 6. Assessment of resistance of lupine rhizobia strains to sulfate-chloride salinity, $\%$ 
This is characteristic for both neutral and sodium salinization. Out of the three strains of nodule bacteria studied, sample $367 \mathrm{a}$ was the most salttolerant. Strains 363a and 375a were less resistant to salinity.

\section{REFERENCES}

1. Laktionov Yu.V., Kosulnikov Yu.V., Dudnikova D.V., Yakhno V.V., Kozhemyakov A.P. 2019. Assessment of resistance of soybean nodule bacteria strains to recommended chemical fungicides. Grain farming in Russia, 1 (61), 62-67.

2. Laktionov Yu.V., Yakhno V.V., Kozhemyakov A.P. 2018. New approaches in cultivation and application of microbiological preparations for crop production. Materials of the III International Scientific Conference, 38-39.

3. Muntyan V.S., Akinina Yu.N., Simarov B.V., Rumyantseva M.L. 2018. Analysis of structural polymorphism of the puta gene involved in proline metabolism in natural strains of Sinorhizobium meliloti. Current biotechnology, 3(26), 429-431.

4. Patent for invention RU 2593714 C1. Strain of nodule bacteria of alfalfa Sinorhizobium meliloti - symbiotic nitrogen fixator for normal and saline soils. 2015.

5. Petukhova V.S., Skipin L.N., Bogdanova O.G. 2017. Improvement of methods of drilling mud recultivation.

6. Posypanov, G.S. 1991. Methods of studying the biological fixation of air nitrogen.

7. Rumyantseva M.L., Muntyan V.S., Cherkasova M.E., Saksaganskaya A.S., Andronov E.E., Simarov B.V. 2018. Genomic islands in sinorhizobium meliloti RM1021, nitrogen-fixing symbiont of alfalfa. Russian Journal of Genetics, 54 (7), 759-769.
8. Rumyantseva M.L., Vladimirova M.E., Muntyan V.S., Stepanova G.V., Saksaganskaya A.S., Kozhemyakov A.P., Orlova A.G., Becker A., Simarov B.V. 2019. Highly effective strains of nodule bacteria of alfalfa (Medicago Varia L.): molecular-genetic characteristics and use in conjugated breeding. Agricultural biology, 54 (6), 1306-1323.

9. Saksaganskaya A.S., Kozlova A.P., Muntyan V.S., Rumyantseva M.L. 2017. Dynamics of nodule formation on alfalfa roots by Sinorhizobium meliloti strains of different NOD genotypes. Collection of articles based on the materials of the $\mathrm{V}$ International Scientific and Practical Conference, 50-56.

10. Saksaganskaya A.S. Muntyan V.S., Rumyantseva M.L. 2016. Polymorphism of nodule bacteria Sinorhizobium meliloti determining virulence and stress resistance. In book: biology - Science of the XXI century, 44-45.

11. Skipin L.N. 2000. Solontsy Sibiri: ecological aspects of development.

12. Skipin L.N., Petukhova V.S., Perfiliev N.V., Khramtsov N.V. 2014. Parameters of vital activity of nodule bacteria under changes in edaphic factors. Bulletin of KrasGAU, 6 (93), 103-108.

13. Yakobi L.M., Zheleznyakov S.V., Smetanin R.V., Lebedeva V.K., Kozhemyakov A.P. 2019. Investigation of the induced mutant of alfalfa hop (Medicagolupulinal. SUBSP. Vulgariskoch) on symbiotic signs in the formation of mycorrhizal symbiosis. Collection of theses of the International Congress.

14. Yakobi L.M., Zheleznyakov S.V., Kozhemyakov A.P. 2018. Morphological description of non-effective arbuscular mycorrhiza developed by plant mutant (Medicago lupulina L. Subsp. Vulgaris koch.) in association with rhizophagus irregularis. In the book: Materials of the International Scientific Conference.

15. Yezhov G.I. 1981. Guide to practical tasks in agricultural microbiology. 